J Am Chem Soc. 2016 October 12; 138(40): 13353-13360. doi:10.1021/jacs.6b07890.

\title{
Alcohol, Aldehyde, and Ketone Liberation and Intracellular Cargo Release through Peroxide-Mediated $a$-Boryl Ether Fragmentation
}

\author{
Ramsey D. Hanna, Yuta Naro, Alexander Deiters`, Paul E. Floreancig ${ }^{\star}$ \\ Department of Chemistry, University of Pittsburgh, Pittsburgh, Pennsylvania 15260, United States
}

\begin{abstract}
$a$-Boryl ethers, carbonates, and acetals, readily prepared from the corresponding alcohols that are accessed through ketone diboration, react rapidly with hydrogen peroxide to release alcohols, aldehydes, and ketones through the collapse of hemiacetal intermediates. Experiments with $a$ boryl acetals containing a latent fluorophore clearly demonstrate that cargo can be released inside cells in the presence of exogenous or endogenous hydrogen peroxide. These experiments show that this protocol can be used for drug activation in an oxidative environment without generating toxic byproducts.
\end{abstract}

\section{Graphical Abstract}
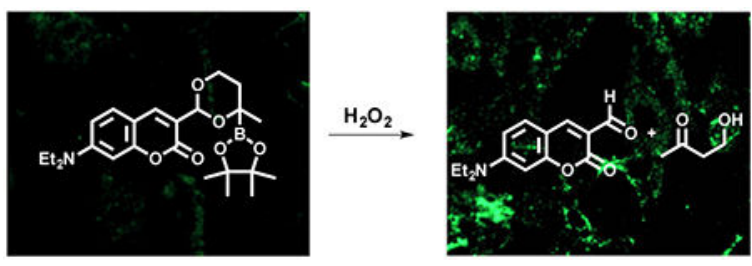

\section{INTRODUCTION}

Reactive oxygen species (ROS), including hydrogen peroxide, are linked to a number of disparate medical conditions including neurological diseases, ${ }^{1}$ cancer, ${ }^{2}$ aging, ${ }^{3}$ and diabetes.

${ }^{4}$ ROS-rich environments are also created through exposure to ionizing radiation, as encountered in radiotherapy. ${ }^{5}$ Hydrogen peroxide's unique reactivity properties and importance in these conditions have resulted in its utilization to initiate a number of processes in biological and materials chemistry. Initial studies from Chang's group demonstrated that aryl boronates can be converted to fluorescent phenols by cellular $\mathrm{H}_{2} \mathrm{O}_{2}{ }^{6}$ This result, coupled with Lo's employment of the boronate to phenol conversion to effect

\footnotetext{
‘Corresponding Authors: deiters@pitt.edu, florean@pitt.edu.

Supporting Information

The Supporting Information is available free of charge on the ACS Publications website at DOI: 10.1021/jacs.6b07890.

Schemes for compound synthesis, characterization of all compounds, general protocols for compound release, and procedures for fluorophore release in cells (PDF)

The authors declare the following competing financial interest(s): The authors have applied for a provisional patent covering the drug release applications of this work.
} 
benzylic leaving group departure, ${ }^{7}$ led to the development of numerous compounds that release fluorophores and other diagnostic tools in oxidatively stressed cells. ${ }^{8}$ Additional applications of oxidatively triggered self-immolative spacers ${ }^{9}$ have been developed to promote particle breakdown ${ }^{10}$ and signal amplification. ${ }^{11} \mathrm{H}_{2} \mathrm{O}_{2}$ is an attractive agent for initiating prodrug unraveling in many cases because it is small and can access sterically hindered sites in structures that are inaccessible to enzymes, which are commonly utilized for this purpose. Cargo release from antibodies ${ }^{12}$ serves as an example of a process that can benefit from activation by a small molecule. Peroxide-mediated drug release has been explored to a limited extent. ${ }^{13}$ However, substrates for these processes employ aryl or vinyl boronates as oxidative triggers to promote release from the benzylic or allylic position. Therapeutic applications of these systems, therefore, can be complicated by the significant toxicity of the resultant quinone methide ${ }^{14}$ or acrolein ${ }^{15}$ byproducts. Thus, alternative structural motifs that release compounds in the presence of $\mathrm{H}_{2} \mathrm{O}_{2}$ without generating toxic byproducts would be valuable for applications in oxidative drug release.

We have initiated a program with the objective of designing readily accessible structures that have the capacity to localize toward a cellular target and decompose under oxidative conditions to release a biological effector. Our initial design for alcohol release ${ }^{13 b}$ (Scheme 1) employed acyl aminal substrates (1) that are available through reductive multicomponent unions of nitriles, chloroformates, and alcohols. ${ }^{16}$ Aryl or vinyl boronate oxidation with $\mathrm{H}_{2} \mathrm{O}_{2}$ releases a quinone methide or acrolein and $\mathrm{CO}_{2}$ to form an unstable hemiaminal (2) that collapses to release the alcohol. We reasoned that oxidation of $a$-boryl ethers or carbonates (3) would provide a similar unstable hemiacetal (4) that releases an alcohol directly or through carbonate breakdown with less byproduct generation. This approach allows for the selection of a non-toxic ketone byproduct to serve as a guide in substrate design.

This manuscript describes the realization of this approach through the release of several diverse structures via oxidative fragmentation of $a$-boryl ethers, carbonates, and acetals. Specific advances include (1) the development of experiment-tally facile conditions for the synthesis of $a$-boryl alcohols through a variant of a known ketone diboration protocol, (2) the preparation of $a$-boryl ethers and carbonates through conditions that avoid strong base, (3) the demonstration that $a$-boryl ethers decompose rapidly and efficiently in the presence of $\mathrm{H}_{2} \mathrm{O}_{2}$ under mildly basic conditions while $a$-boryl carbonates decompose more slowly, 4) the elaboration of several protocols for preparing cyclic boryl-substituted acetals, (5) the observation that the acetals can liberate aldehydes and ketones in the presence of $\mathrm{H}_{2} \mathrm{O}_{2}$, (6) the application of the acetal breakdown to release fluorophores at low substrate and peroxide concentrations, (7) the validation of the capacity of the acetals to release cargo in cells through stimulation with exogenous $\mathrm{H}_{2} \mathrm{O}_{2}$, and (8) the demonstration that cargo can be released in cells by endogenous $\mathrm{H}_{2} \mathrm{O}_{2}$ resulting from chemically stimulated oxidative stress. These results clearly illustrate that $\boldsymbol{a}$-boryl ethers, carbonates, and acetals are viable substrates for releasing biological effectors in cells in response to oxidative conditions while avoiding the generation of toxic byproducts. 


\section{RESULTS AND DISCUSSION}

\section{Ether, Carbonate, and Cyclic Acetal Substrate Synthesis and Decomposition.}

The success of this project was contingent upon identifying suitable approach to $a$-boryl alcohol formation. ${ }^{17}$ We initially employed Clark's ketone-relevant variation ${ }^{18}$ of the Sadighi carbonyl diboration protocol ${ }^{19}$ for the conversion of 5 to boryl alcohol $\mathbf{6}$ (Scheme 2) ${ }^{20}$ These conditions (PinB-BPin, (ICy)CuCl, $\mathrm{NaO} t-\mathrm{Bu}, \mathrm{PhMe}, 50{ }^{\circ} \mathrm{C}$ followed by borate protodeboration on silica gel) provided 6 but were deemed unacceptable due to the low reaction rate and the technical difficulty associated with the need to initiate the reaction in a glovebox. We reasoned that the relevant copper carbene catalyst could be prepared in situ by deprotonating the imidazolium salt in the presence of $\mathrm{CuCl}$, thereby obviating the need to isolate this sensitive species. Moreover, adding $\mathrm{MeOH}$ to the reaction mixture substantially increased the rate of the reaction, in accord with Molander's observations. ${ }^{21}$ These changes resulted in the conversion of 5 to $\mathbf{6}$ in $82 \%$ yield within $1 \mathrm{~h}$ and without recourse to glovebox or Schlenk line techniques. The experimental facility of this protocol appreciably enhances access to $a$-boryl alcohols. This is significant because boronates and related species with $a$ heteroatom substitution are useful as substrates for cross-coupling ${ }^{21}$ and chain-elongation reactions ${ }^{22}$ and as surrogates of functionalized carboxylic acids for applications in medicinal chemistry. ${ }^{23}$ The hydroxy groups can be functionalized readily, as demonstrated through the formation of methoxymethyl ether $\mathbf{7}$ and phenyl carbonate $\mathbf{8}$.

The oxidative breakdown of compounds $\mathbf{7}$ and $\mathbf{8}$ was achieved by subjecting them ( $25 \mathrm{mM})$ to urea $\cdot \mathrm{H}_{2} \mathrm{O}_{2}(300 \mathrm{mM})$ in a mixture of $\mathrm{CD}_{3} \mathrm{CN}$ and aqueous $\left(\mathrm{D}_{2} \mathrm{O}\right)$ buffer $(\mathrm{pH}$ 8.0). The buffer was selected to mimic the experimentally determined $\mathrm{pH}$ of mitochondria ${ }^{24}$ in consideration of potential applications to mitigating neuronal oxidative stress. Initial experiments were conducted in a 5:1 ratio of $\mathrm{CD}_{3} \mathrm{CN}$ and buffer (Scheme 3). Reaction progress was monitored by ${ }^{1} \mathrm{H}$ NMR through following the disappearance of the signals for diastereotopic hydrogens from the methylene group in the starting materials and the appearance of the corresponding enantiotopic hydrogens in butanone. Conversions were calculated by comparison to the internal standard 1,2-dimethoxyethane.

Methoxymethyl ether 7 fragmented quite rapidly in the presence of hydrogen peroxide. Over $50 \%$ of the starting material was consumed in less than 2 min (Figure 1A), and complete conversion was observed within 20 min with an $89 \%$ NMR yield of butanone. Changing the solvent to a 1:1 ratio of $\mathrm{CD}_{3} \mathrm{CN}$ to buffer did not slow the reaction and resulted in a slightly increased NMR yield of $94 \%$. Moreover lowering the $\mathrm{pH}$ to a cytosolic-relevant value of 7.2 had only a minimal effect on the rate despite the diminished peroxy anion concentration (Figure 1B), providing a 91\% NMR yield of butanone.

Carbonate 8, however, broke down much more slowly under the oxidative conditions. ${ }^{25}$ Consumption of $50 \%$ of the starting material required $22 \mathrm{~min}$ when the reaction was conducted in a 5:1 mixture of $\mathrm{CD}_{3} \mathrm{CN}$ and buffer. Changing the solvent to a 1:1 mixture of $\mathrm{CD}_{3} \mathrm{CN}$ and buffer resulted in a slightly increased rate, with $50 \%$ of the starting material being consumed within $12 \mathrm{~min}$. The reactions were quite efficient, with both providing an $84 \%$ yield of the desired products. 
The rate difference for alcohol release between acetal and carbonate substrates indicates that the rate-determining step in these processes is boronate oxidation rather than hemiacetal collapse. The slow breakdown of the carbonate could result from intramolecular coordination between the carbonyl oxygen and the boron, as illustrated by 9 (Figure 2) thereby inhibiting the approach of $\mathrm{HOO}^{-}$to the boron. Crystal structures show this type of coordination in $a$-boryl amides, ${ }^{26}$ and intramolecular coordination has been shown to confer stability to boronates. ${ }^{27}$ However, the ${ }^{11} \mathrm{~B}$ chemical shift of $\mathbf{8}(\delta 32.2 \mathrm{ppm})$ is nearly identical to the ${ }^{11} \mathrm{~B}$ chemical shift in $7(\delta 32.1 \mathrm{ppm})$ and is significantly different from that of amido pinacolboronates, which show ${ }^{11} \mathrm{~B}$ chemical shifts of approximately $15 \mathrm{ppm} .{ }^{26,28}$ Alternatively the breakdown could be slowed by a diminished migratory aptitude resulting from the presence of an electron withdrawing acyl group. No evidence of a persistent peroxyboronate intermediate, such as $\mathbf{1 0}$, was observed upon monitoring the progress of the reaction with ${ }^{11} \mathrm{~B}$ NMR, however. Regardless of the origin of the effect, the capacity to control the breakdown rate through a simple structural modification provides kinetic versatility in drug release strategy.

Several additional substrates were prepared to define the scope of the process (Table 1). Secondary alcohols such as cyclohexanol (from the breakdown of 11) and the more complex menthol (from the breakdown of 13) are released smoothly. Although the formation and fragmentation of alkoxymethyl ethers proceed rapidly and smoothly, direct release of alcohols would be desirable for avoiding the generation of toxic formaldehyde, ${ }^{29}$ particularly if the cargo is not intended to effect a cytotoxic response. Primary and secondary alcohols can be released directly, as shown in entries 3-5. The use of an aldehyde-derived boronate in entry 5 facilitated the synthesis of the ether. The oxidative cleavage of $\mathbf{1 5}$ and $\mathbf{2 0}$ (entries 3 and 6) are also significant because they show that functionalized substrates participate well in this process, providing potential handles for incorporating tissue-, cell-, or organelle-targeting functional groups. Boronate $\mathbf{2 0}$ releases the antioxidant pentamethyl chromanol (21), ${ }^{30}$ showing that this method could be applied to the release of radical scavengers in the presence of environments that are rich in reactive oxygen species, such as mitochondria. As previously discussed, this release was predictably somewhat slow due to the carbonate linker. The release of carboxylic acids (entry 7), while possible, is substantially slower than the release of alcohols or carbonates and is therefore not likely to be useful. Compound 22 showed a chemical shift of $27.0 \mathrm{ppm}$ in the ${ }^{11} \mathrm{~B}$ NMR spectrum, indicating that coordination between the boron and the carbonyl group is likely to play a role in preventing oxidative cleavage through peroxide attack.

The synthesis of alkyl ethers is challenging in comparison to the synthesis of alkoxymethyl ethers because direct Williamson ether syntheses with $a$-boryl alcohols are prone to undergo bora-Brook rearrangements ${ }^{31}$ that render the oxygen non-nucleophilic. Direct etherification requires sufficiently potent electrophiles to subvert the need for alkoxide generation. This can be achieved (Scheme 4) by activating halide leaving groups with AgOTf, ${ }^{32}$ allowing for hindered pyridines to be used as proton scavengers. This is illustrated by the ethylation of $a$ boryl alcohol $\mathbf{2 4}$ to yield $\mathbf{1 5}$. Alternatively, reductive etherification of $a$-boryl silyl ethers in the presence of $\mathrm{BiBr}_{3}{ }^{33}$ is a versatile method for preparing these substrates under non-basic conditions. Thus, silyl ether $\mathbf{2 5}$, readily available from $\mathbf{6}$, can be condensed with 
isobutyraldehyde in the presence of $\mathrm{Et}_{3} \mathrm{SiH}$ to yield 17. An additional benefit of the reductive annulation protocol lies in the enhanced stability of $a$-boryl silyl ethers in comparison to $a$-boryl alcohols. This allows for the substrate scope to be broadened to include aldehyde-derived boronates such as $\mathbf{1 9}$.

The functional group tolerance of the process and the capacity for $a$-boryl alcohols to add into oxocarbenium ions suggested that the scope could be expanded further to promote aldehyde and ketone release. The preparation of the substrates for these studies is illustrated in Scheme 5. Cyclic acetal substrates can be prepared either through oxidative or classical exchange reactions. Ketone 26, available from commercially available 4-hydroxy-2butanone, ${ }^{34}$ underwent copper-catalyzed borylation smoothly to yield alcohol 27 . DDQmediated oxidative cyclization ${ }^{35}$ provided acetal 28 in $78 \%$ yield. Removing the PMB group from 27 under hydrogenolytic conditions followed by acetal exchange with the dimethyl acetal of benzophenone provided acetal $\mathbf{2 9}$ in $49 \%$ yield over two steps.

The boryl-substituted acetals release their cargo readily, as shown in Scheme 6. Boronate $\mathbf{2 8}$ reacted with $\mathrm{H}_{2} \mathrm{O}_{2}$ at $\mathrm{pH} 8.0$ to provide hemiacetal 30, which broke down to form anisaldehyde and 1-hydroxy-3-butanone in $94 \%$ yield. Over $50 \%$ of the starting material was consumed within $90 \mathrm{~s}$, and complete conversion occurred in $<15 \mathrm{~min}$. Similarly, boronate 29 reacted to form benzophenone quickly and efficiently. Therefore, this variation of the protocol significantly extends the range of structures that can be released in the presence of hydrogen peroxide. Moreover, this strategy illustrates a new approach to designing prodrugs for aldehydes and ketones, as previous efforts have largely centered on the use of oximes and derivatives. ${ }^{36,37}$

\section{Latent Fluorophore Synthesis and Release.}

All studies to this point were conducted at relatively high concentrations of substrate and peroxide. Determining whether these processes can proceed at biologically relevant concentrations requires an analytical technique that is more sensitive than ${ }^{1} \mathrm{H}$ NMR. Therefore, we explored the potential for the release of a fluorophore at low substrate and peroxide concentrations. The synthesis of a latent fluorophore is shown in Scheme 7. Silyl ether 31, which was prepared from the TBS ether of 4-hydroxy-2-butanone, coupled with aldehyde 32 (prepared from commercially available materials in two steps) ${ }^{38}$ in the presence of TMSOTf ${ }^{39}$ to yield acetal 33. This acetal was formed as a single stereoisomer, with the relative configuration being determined through a NOESY experiment. The Noyori acetalization conditions were significantly superior to those of Brønsted acid mediated protocols due to the absence of protodeboration as a prominent competing reaction. Acetalization induces significantly different fluorescence properties relative to the aldehyde, with $\lambda_{\text {ex }}$ values of 448 and $402 \mathrm{~nm}$ and $\lambda_{\text {em }}$ values of 510 and $452 \mathrm{~nm}$ for $\mathbf{3 2}$ and $\mathbf{3 3}$, respectively, thereby facilitating the monitoring of oxidative breakdown. Acetal 34 was prepared through a similar protocol to serve as a control compound in evaluating the importance of the oxidative trigger in peroxide-mediated decomposition. We also prepared benzylic carbonate 35 . This compound releases its fluorophore through the common oxidative 1,6-elimination pathway and was synthesized to compare the background stability of $\mathbf{3 3}$ with a well-vetted latent fluorophore motif. 
Fluorophore release was studied at a concentration of $25 \mu \mathrm{M}$ for 33 at pH 7.4 with $\mathrm{H}_{2} \mathrm{O}_{2}$ concentrations of 100 and $200 \mu \mathrm{M}$. The concentration of $\mathbf{3 2}$ was monitored by excitation at $448 \mathrm{~nm}$ and emission at $499 \mathrm{~nm}$ (a wavelength where $\mathbf{3 3}$ shows only slight emission), with product release being quantitated by comparison to a standard curve. The fluorophore release experiments are summarized in Figure 3. The breakdown of $\mathbf{3 3}$ was conducted in $1 \%$ DMSO in aqueous phosphate buffer. Fluorophore concentration increased steadily with time. The rate and extent of fluorophore release showed the expected dependency upon $\mathrm{H}_{2} \mathrm{O}_{2}$ concentration. Lowering the $\mathrm{H}_{2} \mathrm{O}_{2}$ concentration from 200 to $100 \mu \mathrm{M}$ slowed fluorophore release to a small but noteworthy extent. The yield of $\mathbf{3 2}$ was $88 \%$ with $200 \mu \mathrm{M} \mathrm{H}_{2} \mathrm{O}_{2}$ and $78 \%$ with $100 \mu \mathrm{M} \mathrm{H}_{2} \mathrm{O}_{2}$. Fluorophore release was minimal in the absence of $\mathrm{H}_{2} \mathrm{O}_{2}$. A similar study of carbonate $\mathbf{3 5}$ showed that ratio of fluorophore release in the presence and absence of $\mathrm{H}_{2} \mathrm{O}_{2}$ was nearly equivalent to the ratio that was observed for 33.25 This indicates that the inherent stability of the $a$-boryl ether moiety is comparable to a well established oxidative trigger. Fluorophore release in the absence of $\mathrm{H}_{2} \mathrm{O}_{2}$ was studied at $\mathrm{pH} 6.0$ and 4.5 to determine the stability of the acetal toward acid. Fluorophore release was slightly inhibited at lower $\mathrm{pH}$ values (see the Supporting Information for a graphic with an expanded $y$-axis), which is significant for biological applications in consideration of the capacity of endosomes to achieve $\mathrm{pH}$ values as low as $\mathbf{4 . 9} .{ }^{40}$

Acetal 34 did not release 32 at any $\mathrm{H}_{2} \mathrm{O}_{2}$ concentration over the time span of the experiment, 25 thereby validating the importance of boronate oxidation in cargo release. Separate studies in the presence of a large excess of $\mathrm{H}_{2} \mathrm{O}_{2}(10 \mathrm{mM})$ allowed for the determination of a pseudo-first-order rate constant of $1.47 \times 10^{-3} \mathrm{~s}^{-1}$ for the decomposition of $33 .{ }^{25}$ This rate compares favorably to the peroxide-mediated decomposition of boryl-substituted benzylic carbamates to generate quinone methides via 1,6-elimination. ${ }^{8 \mathrm{a}}$ The 1,6-elimination protocol is likely to be significantly slower for releasing aliphatic alcohols, however, in consideration of their lower nucleofugacity and our prior observation ${ }^{13 b}$ that the rates of these processes are strongly correlated with the rate of benzylic $\mathrm{C}-\mathrm{O}$ bond cleavage. ${ }^{41}$

Exposing $\mathbf{3 3}$ to a number of reactive oxygen species showed that the breakdown is selective for $\mathrm{H}_{2} \mathrm{O}_{2}$ (Figure 4). Solutions of $\mathrm{H}_{2} \mathrm{O}_{2}, \mathrm{NaOCl}, \mathrm{KO}_{2}$, and $t \mathrm{BuOOH}$ were prepared by diluting commercially available material. Hydroxyl and $t$-butoxyl radicals were prepared by mixing the corresponding peroxide with $\mathrm{FeSO}_{4} \cdot 5 \mathrm{H}_{2} \mathrm{O}$ and adding catalase to consume residual peroxide. ${ }^{8 a}$ The chart shows the ratio of fluorescence intensity after $30 \mathrm{~min}$ to the initial value. Aside from $\mathrm{H}_{2} \mathrm{O}_{2}$, only hydroxyl radical showed a notable fluorophore release, albeit significantly lower in magnitude compared to that of $\mathrm{H}_{2} \mathrm{O}_{2}$-mediated release.

\section{Cellular Fluorophore Release.}

These results led us to study the release of the fluorophore in cells to provide an easily visualized demonstration of these compounds' capacity to release cargo in a biologically relevant environment. This was demonstrated in accord with Chang's protocol, ${ }^{42}$ whereby HeLa cells were incubated with $\mathbf{3 3}(10 \mu \mathrm{M})$ for $45 \mathrm{~min}$ and fluorophore release was imaged in the absence and presence of exogenous $\mathrm{H}_{2} \mathrm{O}_{2}(100 \mu \mathrm{M})$. The results are shown in Figure 5. Very little fluorophore release occurred within 30 min in the absence of external $\mathrm{H}_{2} \mathrm{O}_{2}$. Significant fluorophore release was observed in the presence of $\mathrm{H}_{2} \mathrm{O}_{2}$, however. This 
demonstrates that $a$-boryl acetals are cell-permeable and can release cargo within cells. Conducting these studies with control acetal $\mathbf{3 4}$ resulted in no fluorophore release, ${ }^{25}$ thereby providing further evidence for the proposed release mechanism.

HeLa cells, directly derived from cancerous cervical tissue, are exprected to contain slightly elevated levels of endogenous $\mathrm{H}_{2} \mathrm{O}_{2}{ }^{43}$ and therefore show higher background emission. We repeated this experiment with $\mathbf{3 3}$ and HEK293T cells, derived from the transformation of noncancerous embryonic kidney tissue ${ }^{44}$ to test whether differentiation between cell lines is possible.

Quantitation of fluorophore release in the absence and presence of exogenous $\mathrm{H}_{2} \mathrm{O}_{2}$ (Figure 6) indeed showed that the background signal was significantly reduced in the absence of exogenous $\mathrm{H}_{2} \mathrm{O}_{2}$. These results further validate the stability of $a$-boryl acetals in the absence of oxidants, as required for selective applications to drug release in oxidatively stressed environments. Conducting these studies with the control acetal $\mathbf{3 4}$ again resulted in no fluorophore release. ${ }^{25}$

While these studies provide compelling evidence for the capacity of $a$-boryl acetals to release cargo in cells, the results would have significantly more impact if fluorophore release could be achieved through endogenous $\mathrm{H}_{2} \mathrm{O}_{2}$ generation. Phorbol myristate acetate (PMA) promotes intracellular $\mathrm{H}_{2} \mathrm{O}_{2}$ generation. ${ }^{45}$ Therefore, HeLa cells were incubated with PMA $(1 \mu \mathrm{M})$ for $60 \mathrm{~min}$ followed by the addition of $\mathbf{3 3}(10 \mu \mathrm{M})$. Fluorophore release in cells that were treated with PMA was evidenced by a significant increase of fluorescence (Figure 7), in contrast to the lack of fluorophore release in cells that were not treated with PMA. These results clearly show the capacity of $a$-boryl acetals to release compounds inside of cells in response to endogenous concentrations of $\mathrm{H}_{2} \mathrm{O}_{2}$.

\section{CONCLUSIONS}

We have shown that $a$-boryl ethers and related structures are excellent vehicles for releasing molecular cargo in an oxidative environment. These compounds are accessed from $\boldsymbol{a}$-boryl alcohols that can be prepared by operationally facile ketone or aldehyde borylation reactions. Although these alcohols cannot be functionalized via their alkoxides, they can be alkylated or acylated in the presence of weak amine bases. Reductive alkylation provides an attractive alternative to boryl ether formation under acidic conditions. $a$-Boryl ethers release alcohols extremely rapidly in the presence of $\mathrm{H}_{2} \mathrm{O}_{2}$, while $a$-boryl carbonates decompose somewhat more slowly, providing a predictable mechanism for controlling the rate of alcohol release. The capacity to functionalize $a$-boryl alcohols under acidic conditions provides a pathway to generate $a$-boryl acetals. These acid-stable structures readily release aldehydes and ketones upon exposure to $\mathrm{H}_{2} \mathrm{O}_{2}$. The ability to liberate cargo at low substrate and peroxide concentrations was validated through the release of a fluorescent aldehyde. Fluorophore release can also be achieved inside cells with exogenous $\mathrm{H}_{2} \mathrm{O}_{2}$ or with endogenous, chemically stimulated $\mathrm{H}_{2} \mathrm{O}_{2}$ generation. The presence of the boronate group is essential to these processes, in support of the proposed pathway for the breakdown. The capacity to release molecules inside cells with a sterically non-demanding oxidant while 
generating non-toxic byproducts indicates that these compounds will be valuable for drug release in oxidatively stressed cells.

\section{Supplementary Material}

Refer to Web version on PubMed Central for supplementary material.

\section{ACKNOWLEDGMENTS}

We thank the National Institutes of Health (AI068021 for P.E.F. and GM112728 for A.D.) and the National Science Foundation (CHE-1362396 for P.E.F.) for generous support of this work. Y.N. was supported in part by a Mellon Graduate Fellowship. We thank Viswanathan Elumalai for assistance with the NMR experiments, and Dr. Detcho Stoyanovsky for valuable discussions.

\section{REFERENCES}

(1). (a)DiMauro S; Schon EA Annu. Rev. Neurosci 2008, 31, 91. [PubMed: 18333761] (b)Lin MT; Beal MF Nature 2006, 443, 787. [PubMed: 17051205] (c)Mattson MP Nature 2004, 430, 631. [PubMed: 15295589]

(2). (a)Fruehauf JP; Meyskens FL Jr. Clin. Cancer Res 2007, 13, 789. [PubMed: 17289868] (b)Wilson WR; Hay MP Nat. Rev. Cancer 2011, 11, 393. [PubMed: 21606941] (c)Ishikawa K; Takenaga K; Akimoto M; Koshikawa N; Yamaguchi A; Imanishi H; Nakada K; Honma Y; Hayashi J Science 2008, 320, 661. [PubMed: 18388260]

(3). (a)Brewer TF; Garcia FJ; Onak CS; Carroll KS; Chang CJ Annu. Rev. Biochem 2015, 84, 765. [PubMed: 26034893] (b)Balaban RS; Nemoto S; Finkel T Cell 2005, 120, 483. [PubMed: 15734681] (c)Finkel T; Holbrook NJ Nature 2000, 408, 239. [PubMed: 11089981]

(4). (a)Houstis N; Rosen ED; Lander ES Nature 2006, 440, 944. [PubMed: 16612386] (b)Pop-Busui R; Sima A; Stevens M Diabetes/Metab. Res. Rev 2006, 22, 257.

(5). Azzam EI; Jay-Gerin J-P; Pain D Cancer Lett. 2012, 327, 48. [PubMed: 22182453]

(6). (a)Chang MCY; Pralle A; Isacoff EY; Chang CJ J. Am. Chem. Soc 2004, 126, 15392. [PubMed: 15563161] (b)Lippert AR; Van De Bittner GC; Chang CJ Acc. Chem. Res 2011, 44, 793. [PubMed: 21834525]

(7). Lo L-C; Chu C-Y Chem. Commun 2003, 39, 2728.

(8). (a)Srikun D; Miller EW; Domaille DW; Chang CJ J. Am. Chem. Soc 2008, 130, 4596. [PubMed: 18336027] (b)Lippert AR; Gschneidtner T; Chang CJ Chem. Commun 2010, 46, 7510.(c)Chung C; Srikun D; Lim CS; Chang CJ; Cho BR Chem. Commun 2011, 47, 9618.(d)Van de Bittner GC; Dubikovskaya EA; Bertozzi CR; Chang CJ Proc. Natl. Acad. Sci. U. S. A 2010, 107, 21316. [PubMed: 21115844] (e)Karton-Lifshin N; Segal E; Omer L; Portnoy M; Satchi-Fainaro R; Shabat D J. Am. Chem. Soc 2011, 133, 10960. [PubMed: 21631116] (f)Yuan L; Lin W; Xie Y; Chen B; Zhu S J. Am. Chem. Soc 2012, 134, 1305. [PubMed: 22148503] (g)Van de Bittner GC; Bertozzi CR; Chang CJ J. Am. Chem. Soc 2013, 135, 1783. [PubMed: 23347279] (h)Carroll V; Michel BW; Blecha J; VanBrocklin H; Keshari K; Wilson D; Chang CJ J. Am. Chem. Soc 2014, 136, 14742. [PubMed: 25310369] (i)Kim J; Park J; Lee H; Choi Y; Kim Y Chem. Commun 2014, 50, 9353.(j)Brooks AD; Mohapatra H; Phillips ST J. Org. Chem 2015, 80, 10437. [PubMed: 26458224] (k)Wang P; Wang K; Chen D; Mao Y; Gu Y RSC Adv. 2015, 5, 85957. (1)Xu J; Zhang Y; Yu H; Gao X; Shao S Anal. Chem 2016, 88, 1455. [PubMed: 26695451] (m)Narayanaswamy N; Narra S; Nair RR; Saini DK; Kondaiah P; Govindaraju T Chem. Sci 2016, 7, 2832. [PubMed: 30090277] (n)Xiao H; Li P; Hu X; Shi X; Zhang W; Tang B Chem. Sci 2016, 7, 6153. [PubMed: 30034754]

(9). For a review on this concept, seeAlouane A; Labruère R; Le Saux T; Schmidt F; Jullien L Angew. Chem., Int. Ed 2015, 54, 7492.

(10). (a)Broaders KE; Grandhe S; Fréchet JMJ J. Am. Chem. Soc 2011, 133, 756. [PubMed: 21171594] (b)Lewis GG; Robbins JS; Phillips ST Macromolecules 2013, 46, 5177.(c)Robbins JS; Schmid KM; Phillips ST J. Org. Chem 2013, 78, 3159. [PubMed: 23414397] (d)Chen C-Y; 
Chen C-T Chem. - Eur. J 2013, 19, 16050. [PubMed: 24123627] (e)Zhao W; Li Y; Yang S; Chen Y; Zheng J; Liu C; Qing Z; Li J; Yang R Anal. Chem 2016, 88, 4833. [PubMed: 27072323]

(11). (a)Roth ME; Green O; Gnaim S; Shabat D Chem. Rev 2016, 116, 1309. [PubMed: 26355446] (b)Sella E; Shabat D Chem. Commun 2008, 5701.(c)Sella E; Shabat DJ J. Am. Chem. Soc 2009, 131, 9934. [PubMed: 19569684] (d)Nuñez SA; Yeung K; Fox NS; Phillips ST J. Org. Chem 2011, 76, 10099. [PubMed: 22092043] (e)Yeung K; Schmid KM; Phillips ST Chem. Commun 2013, 49, 394.(f)Brooks AD; Yeung K; Lewis GG; Phillips ST Anal. Methods 2015, 7, 7186. [PubMed: 26604988] (g)Brooks AD; Mohapatra H; Phillips ST J. Org. Chem 2015, 80, 10437. [PubMed: 26458224]

(12). For a review, seeBo.hme D; Beck-Sickinger AG J. Pept. Sci 2015, 21, 186. [PubMed: 25703117]

(13). (a)Major Jourden JL; Cohen SM Angew. Chem., Int. Ed 2010, 49, 6795.(b)Mosey RA; Floreancig PE Org. Biomol. Chem 2012, 10, 7980. [PubMed: 22936329] (c)Kim E-J; Bhuniya S; Lee H; Kim HM; Cheong C; Maiti S; Hong KS; Kim JS J. Am. Chem. Soc 2014, 136, 13888. [PubMed: 25238144]

(14). (a)Bolton JL Curr. Org. Chem 2014, 18, 61. [PubMed: 25346613] (b)Dufrasne F; Gelbcke M; Neve J; Kiss R; Kraus J-L Curr. Med. Chem 2011, 18, 3995. [PubMed: 21824091]

(15). Kehrer JP; Biswal SS Toxicol. Sci 2000, 57, 6. [PubMed: 10966506]

(16). Wan S; Green ME; Park J-H; Floreancig PE Org. Lett 2007, 9, 5385. [PubMed: 18020344]

(17). For a review, seeClark TB Asian J. Org. Chem 2016, 5, 31.

(18). McIntosh ML; Moore CM; Clark TB Org. Lett 2010, 12, 1996. [PubMed: 20392113]

(19). Laitar DS; Tsui EY; Sadighi JP J. Am. Chem. Soc 2006, 128, 11036. [PubMed: 16925416]

(20). For an enantioselective variant on this protocol, seeKubota K; Yamamoto E; Ito HH J. Am. Chem. Soc 2015, 137, 420. [PubMed: 25494834]

(21). Molander GA; Wisniewski SR J. Am. Chem. Soc 2012, 134, 16856. [PubMed: 23025482]

(22). Moore CM; Medina CR; Cannamela PC; McIntosh ML; Ferber CJ; Roering AJ; Clark TB Org. Lett 2014, 16, 6056. [PubMed: 25412356]

(23). (a)Beenen MA; An C; Ellman JA J. Am. Chem. Soc 2008, 130, 6910. [PubMed: 18461938] (b)Snow RJ; Bachovchin WW; Barton RW; Campbell SJ; Coutts SJ; Freeman DM; Gutheil WG; Kelly TA; Kennedy CA J. Am. Chem. Soc 1994, 116, 10860.(c)Kettner C; Mersinger L; Knabb RJ Biol. Chem 1990, 265, 18289.(d)Adams J; Stein R Annu. Rep. Med. Chem 1996, 31, 279.

(24). (a)Chacon E; Reece JM; Nieminen A-L; Zahrebelski G; Herman B; Lemasters JJ Biophys. J 1994, 66, 942. [PubMed: 8038398] Llopis J; McCaffery JM; Miyawaki A; Farquhar MG; Tsien RY Proc. Natl. Acad. Sci. U. S. A 1998, 95, 6803. [PubMed: 9618493]

(25). Please see the Supporting Information for details and primary data.

(26). Hu N; Zhao G; Zhang Y; Liu X; Li G; Tang WJ Am. Chem. Soc 2015, 137, 6746.

(27). (a)Carry B; Zhang L; Nishiura M; Hou Z Angew. Chem., Int. Ed 2016, 55, 6257.(b)Gillis EP; Burke MD J. Am. Chem. Soc 2008, 130, 14084. [PubMed: 18837550]

(28). Biedrzycki M; Scouten WH; Biedrzycka Z J. Organomet. Chem 1992, 431, 255.

(29). For a report on the carcinogenicity of formaldehyde, seentp.niehs.nih.gov/ntp/roc/content/ profiles/formaldehyde.pdf.

(30). (a)Samhan-Arias AK; Tyurina YY; Kagan VE J. Clin. Biochem. Nutr 2010, 48, 91. [PubMed: 21297919] (b)Staniek K; Rosenau T; Gregor W; Nohl H; Gille L Biochem. Pharmacol 2005, 70, 1361. [PubMed: 16150421]

(31). Kisu H; Sakaino H; Ito F; Yamashita M; Nozaki K J. Am. Chem. Soc 2016, 138, 3548. [PubMed: 26907676]

(32). Burk RM; Gac TS; Roof MB Tetrahedron Lett. 1994, 35, 8111.

(33). Bajwa JS; Jiang X; Slade J; Prasad K; Repič O; Blacklock TJ Tetrahedron Lett. 2002, 43, 6709.

(34). Gathirwa JW; Maki T Tetrahedron 2012, 68, 370.

(35). Oikaw Y; Yoshioka T; Yonemitsu O Tetrahedron Lett. 1982, 23, 889.

(36). (a)Kumpulainen H; Mähönen N; Laitinen M; Jaurakkajärvi M; Raunio H; Juvonen RO; Vepsäläinen J; Järvinen T; Rautio J J. Med. Chem 2006, 49, 1207. [PubMed: 16451086] (b)Foley D; Bailey P; Pieri M; Meredith D Org. Biomol. Chem 2009, 7, 1064. [PubMed: 19262922] 
(37). Although ketone and aldehyde release under endogenous conditions is limited to oximes and derivatives, light-mediated ketone and aldehyde release from acetals has been reported. See(a)Lu M; Fedoryak OD; Moister BR; Dore TM Org. Lett 2003, 5, 2119. [PubMed: 12790543] (b)Kilic F; Kashikar ND; Schmidt R; Alvarez L; Dai L; Weyand I; Wiesner B; Goodwin N; Hagen V; Kaupp UB J. Am. Chem. Soc 2009, 131, 4027. [PubMed: 19256499] (c)Kostikov AP; Malashikhina N; Popik VV J. Org. Chem 2009, 74, 1802. [PubMed: 19146447] (d)Wang P; Hu H; Wang Y Org. Lett 2007, 9, 1533. [PubMed: 17371037] (e)Blanc A; Bochet CG J. Org. Chem 2003, 68, 1138. [PubMed: 12558446]

(38). Wu J-S; Liu W-M; Zhuang X-Q; Wang F; Wang P-F; Tao S-L; Zhang X-H; Wu S-K; Lee S-T Org. Lett 2007, 9, 33. [PubMed: 17192078]

(39). Tsunoda T; Suzuki M; Noyori R Tetrahedron Lett. 1980, 21, 1357.

(40). Huotari J; Helenius A EMBO J. 2011, 30, 3481. [PubMed: 21878991]

(41). A recent report has detailed the influence of leaving groups on the rate of 1,6-elimination. SeeDȩbowska K; Dȩbski D; Michałowski B; Dybala-Defratyka A; Wójcik T; Michalski R; Jakubowska M; Selmi A; Smulik R; Piotrowski L; Adamus J; Marcinek A; Chlopicki S; Sikora A Chem. Res. Toxicol 2016, 29, 735. [PubMed: 27081868]

(42). Dickinson BC; Lin VS; Chang CJ Nat. Protoc 2013, 8, 1249. [PubMed: 23722262]

(43). (a)Verschoor ML; Wilson LA; Singh G Can. J. Physiol. Pharmacol 2010, 88, 204. [PubMed: 20393586] (b)Trush MA; Kensler TW Free Radical Biol. Med 1991, 10, 201. [PubMed: 1864525] (c)Reuter S; Gupta SC; Chaturvedi MM; Aggarwal BB Free Radical Biol. Med 2010, 49, 1603. [PubMed: 20840865]

(44). Lin Y-C; Boone M; Meuris L; Lemmens I; Van Roy N; Soete A; Reumers J; Moisse M; Plaisance S; Drmanac R; Chen J; Speleman F; Lambrechts D; Van de Peer Y; Tavernier J; Callewaert N Nat. Commun 2014, 5, 4767. [PubMed: 25182477]

(45). Bellavite P Free Radical Biol. Med 1988, 4, 225. [PubMed: 2834275] 
A
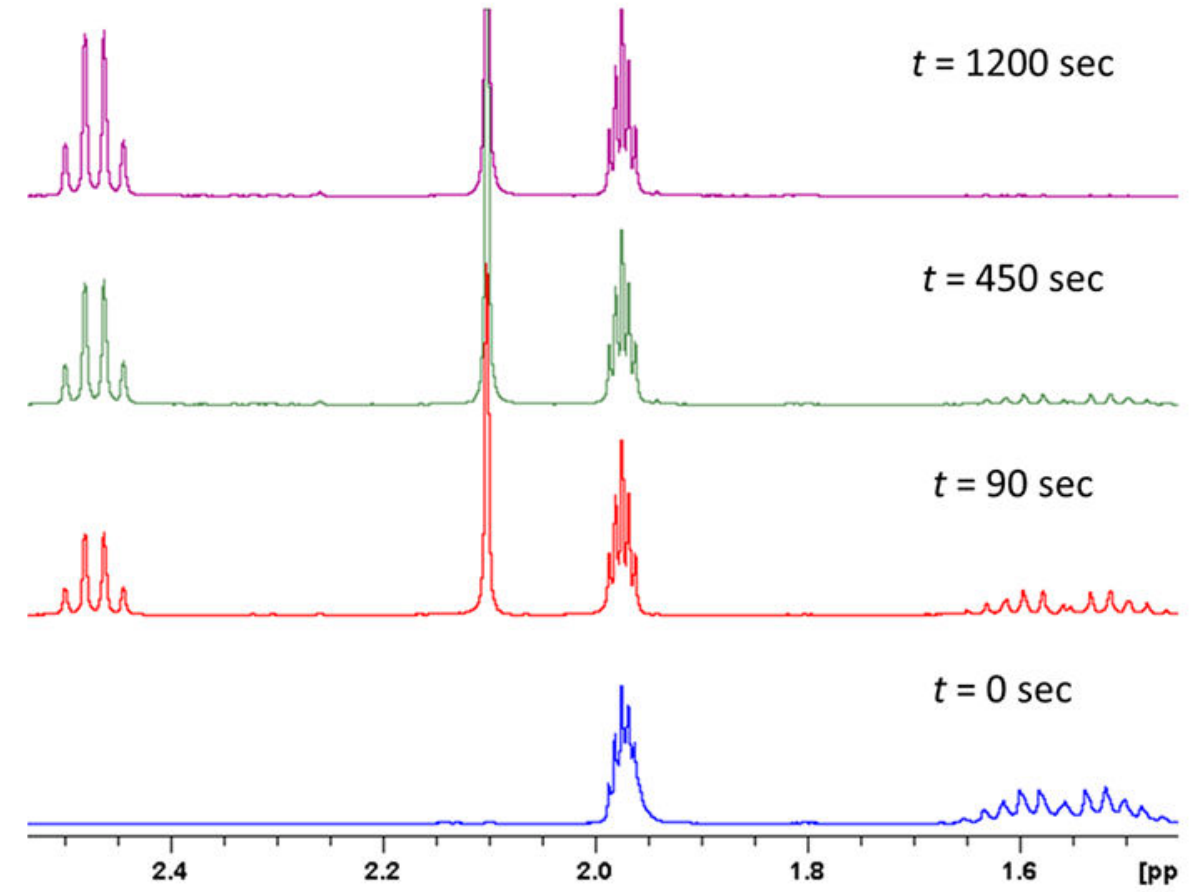

B

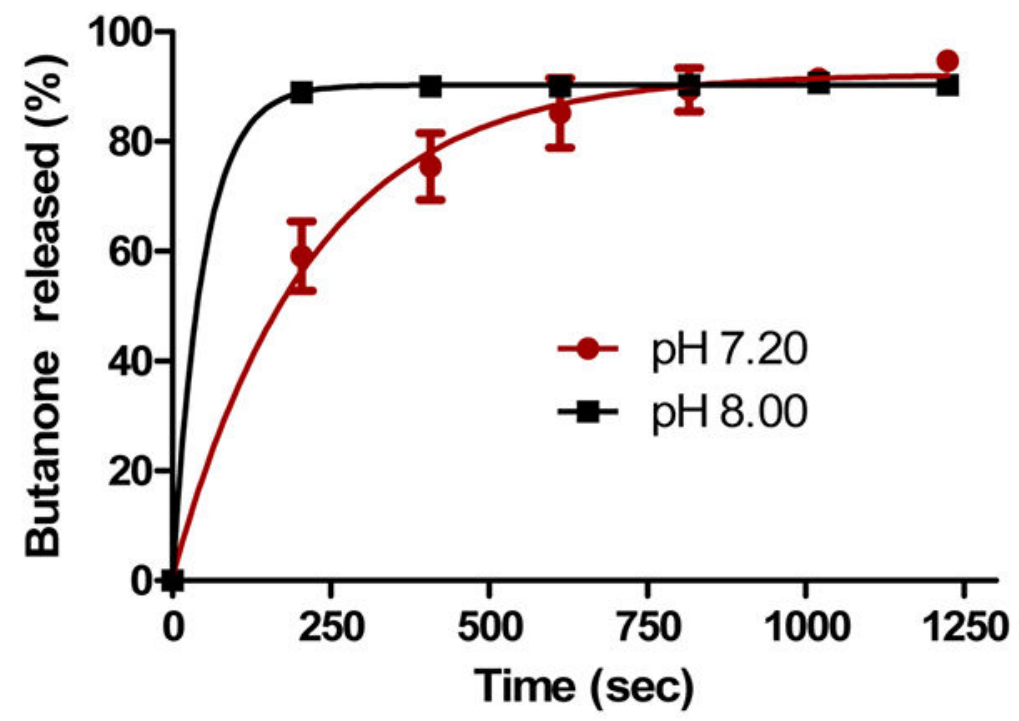

Figure 1.

Oxidative breakdown of 7. (A) Reaction progress as determined by ${ }^{1} \mathrm{H}$ NMR. (B) Reaction progress as a function of $\mathrm{pH}$. 


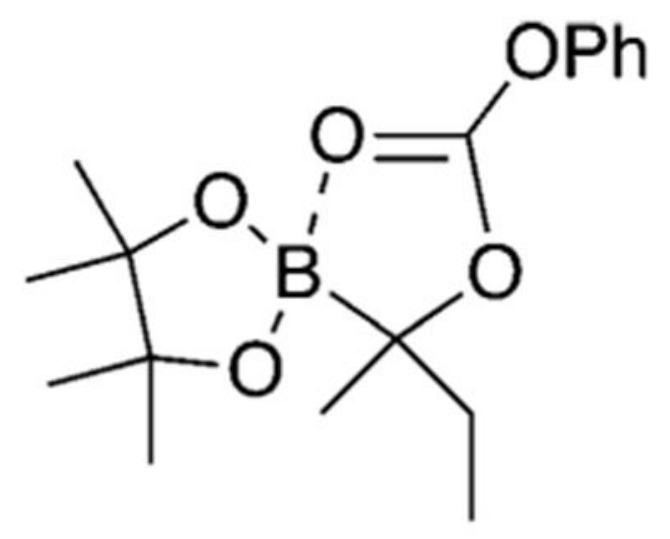

9

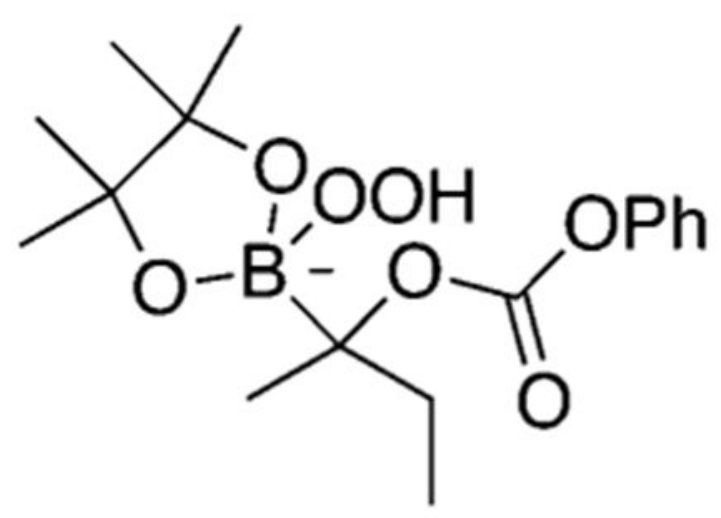

10

Figure 2.

Structures $\mathbf{9}$ and $\mathbf{1 0}$ as potential origins for the slow breakdown of $\mathbf{8}$. 


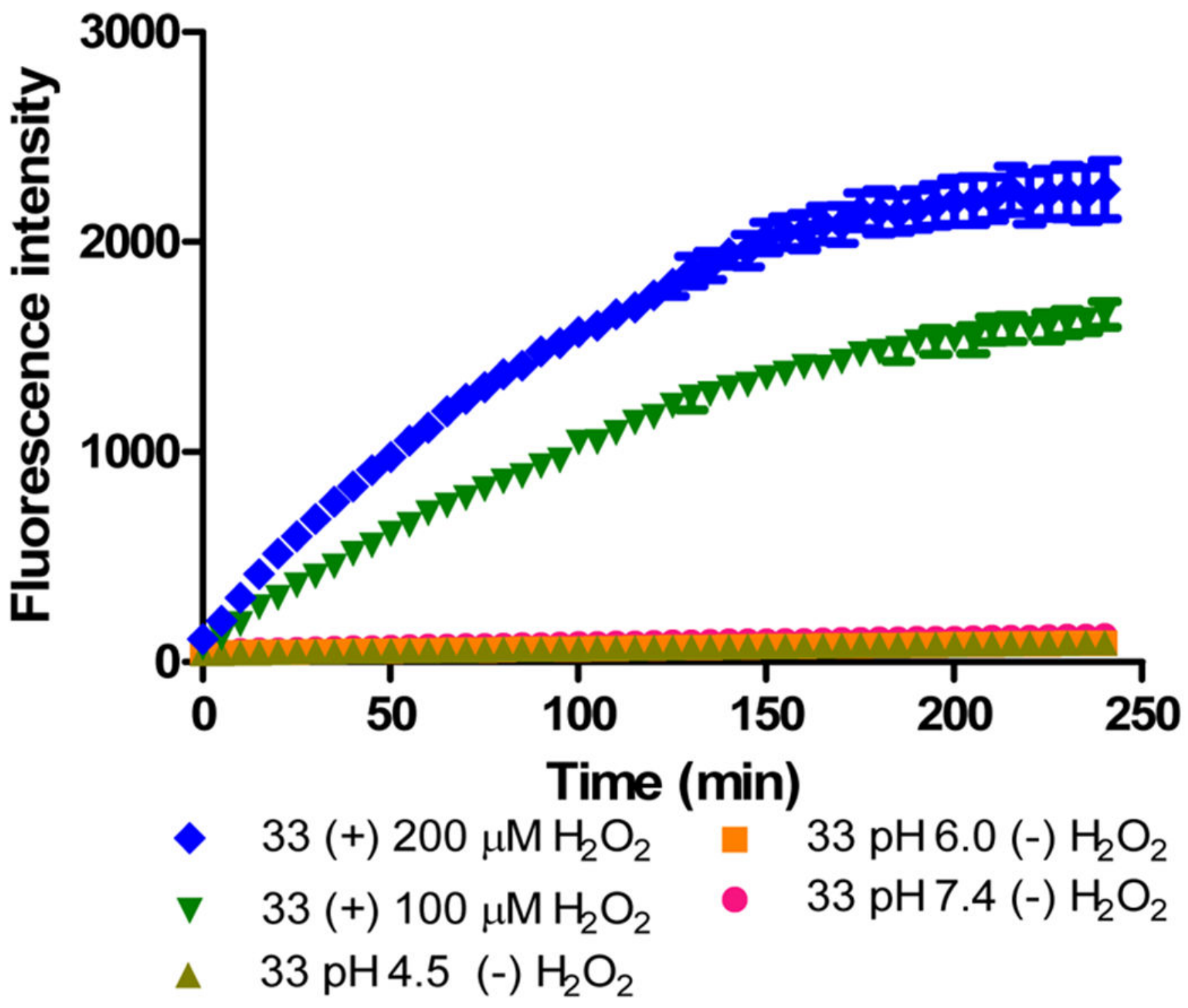

Figure 3.

Fluorophore release at low substrate and peroxide concentrations and $\mathrm{pH}$ stability studies. 


\section{Blank $\quad \mathrm{H}_{2} \mathrm{O}_{2} \quad \mathrm{OCl}^{-} \quad \mathrm{O}_{2}^{-} \mathrm{t}-\mathrm{BuOOH} \cdot \mathrm{OH} \cdot \mathrm{OOt}-\mathrm{Bu}$}

Figure 4.

Comparison of fluorophore release by different oxidants. [33 $]_{0}=40 \mu \mathrm{M}$, [oxidant $]_{0}=200$ $\mu \mathrm{M}, \mathrm{pH} 7.4$. 

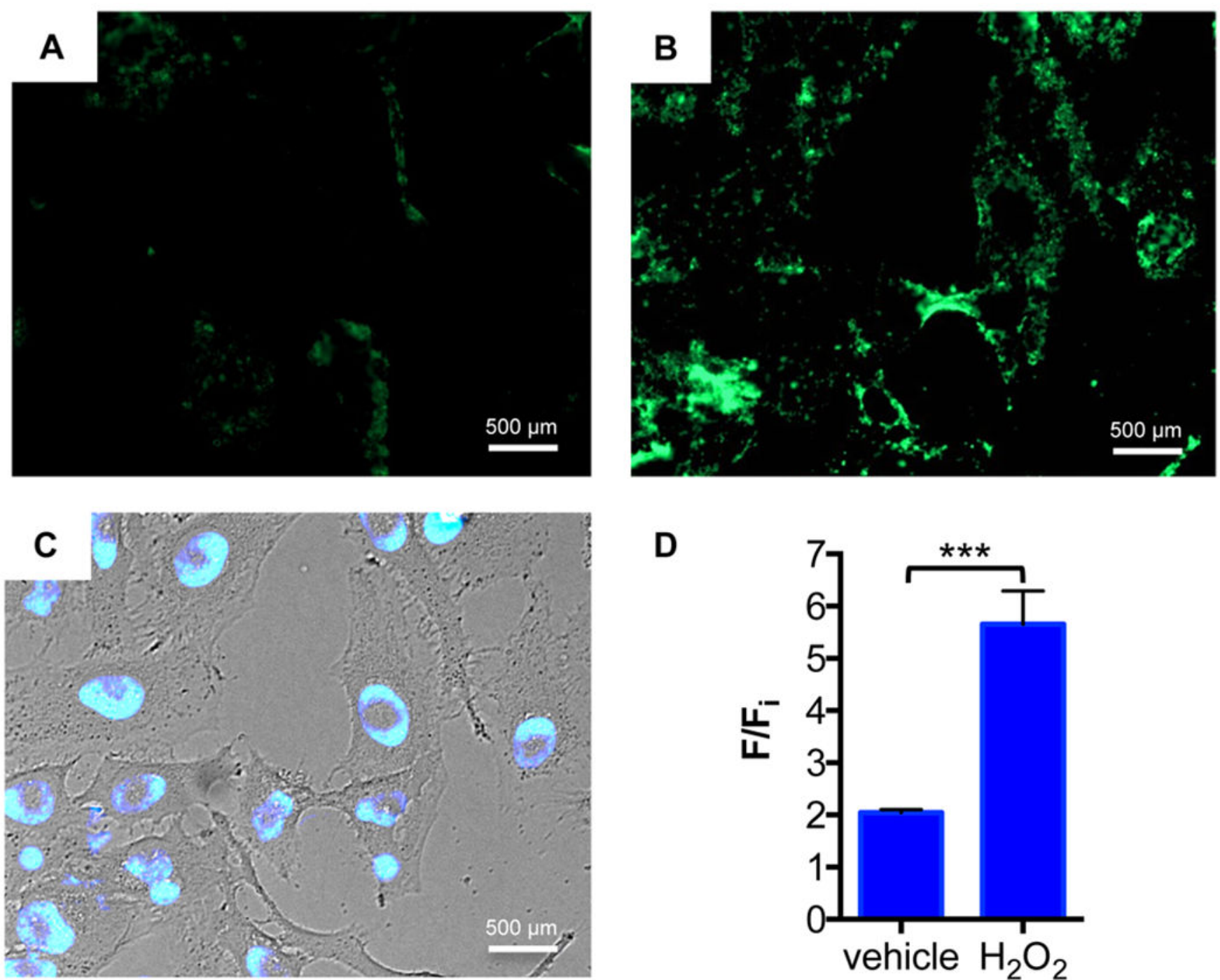

D

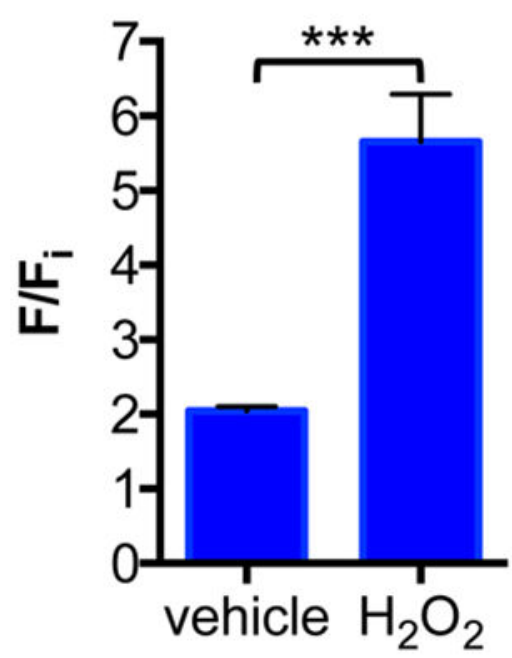

Figure 5.

Fluorophore release in HeLa cells treated with exogenous $\mathrm{H}_{2} \mathrm{O}_{2}$. Cells were incubated with $33(10 \mu \mathrm{M})$ in DPBS buffer for $45 \mathrm{~min}$ at $37^{\circ} \mathrm{C}$, followed by replacement with fresh DPBS containing (A) vehicle or $(\mathrm{B}) \mathrm{H}_{2} \mathrm{O}_{2}(100 \mu \mathrm{M})$. After $30 \mathrm{~min}$, fluorescence was imaged (Zeiss Axio Observer Z1, 20× objective, GFP filter (Set $38 \mathrm{HE}$; ex = $470 \mathrm{~nm}$; em = $525 \mathrm{~nm}$ )). (C) Bright-field image of cells in panel B stained with Hoechst $33258(1 \mu \mathrm{M})$ and imaged using a DAPI filter (Set 68; ex $=377 \mathrm{~nm}$; em = $464 \mathrm{~nm}$ ). (D) Mean fluorescence intensities were calculated from three individual HeLa cells and set relative to the mean fluorescence intensity prior to treatments $\left(F / F_{i}\right)$. Error bars denote standard deviations; ***, $P<0.001$. 

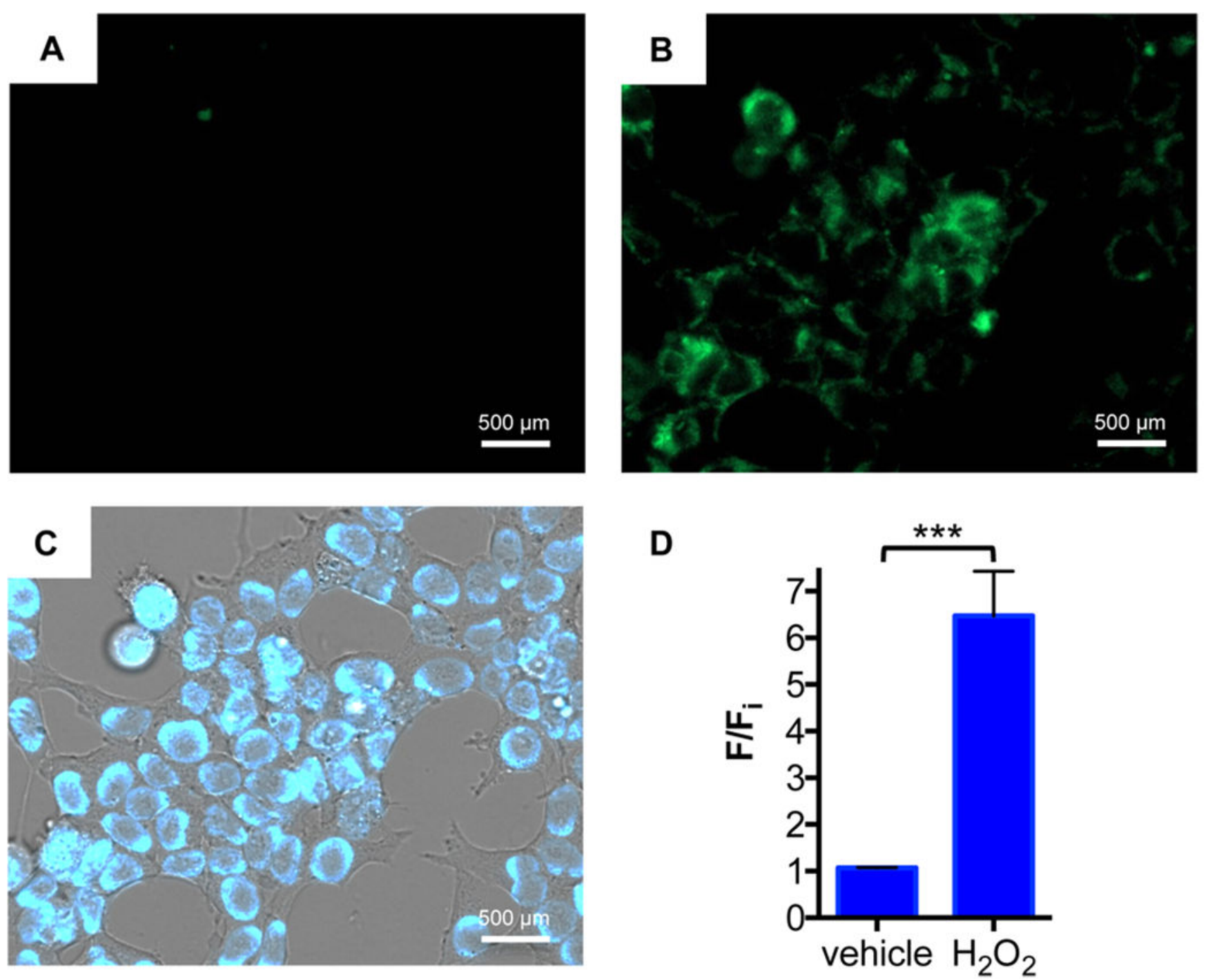

Figure 6.

Fluorophore release in HEK293T cells through treatment with exogenous $\mathrm{H}_{2} \mathrm{O}_{2}$. Cells were treated with $33(10 \mu \mathrm{M})$ in DPBS buffer for $45 \mathrm{~min}$ at $37^{\circ} \mathrm{C}$, followed by replacement with fresh DPBS containing (A) vehicle or (B) $\mathrm{H}_{2} \mathrm{O}_{2}(100 \mu \mathrm{M})$. After 30 min incubation, cellular fluorescence was imaged on a Zeiss Axio Observer Z1 microscope using a 20× objective and GFP (Set $38 \mathrm{HE}$ ) filter ( $\mathrm{ex}=470 \mathrm{~nm}$, em = $525 \mathrm{~nm}$ ). (C) Bright-field image of cells in panel B stained with Hoechst $33258(1 \mu \mathrm{M})$ and imaged using a DAPI (Set 68) filter (ex = $377 \mathrm{~nm}$, em $=464 \mathrm{~nm}$ ). (D) Mean fluorescence intensities were calculated from individual ROIs $(n=3)$ and set relative to the mean fluorescence intensity prior to treatments $\left(F / F_{i}\right)$.

Error bars denote standard deviations. 

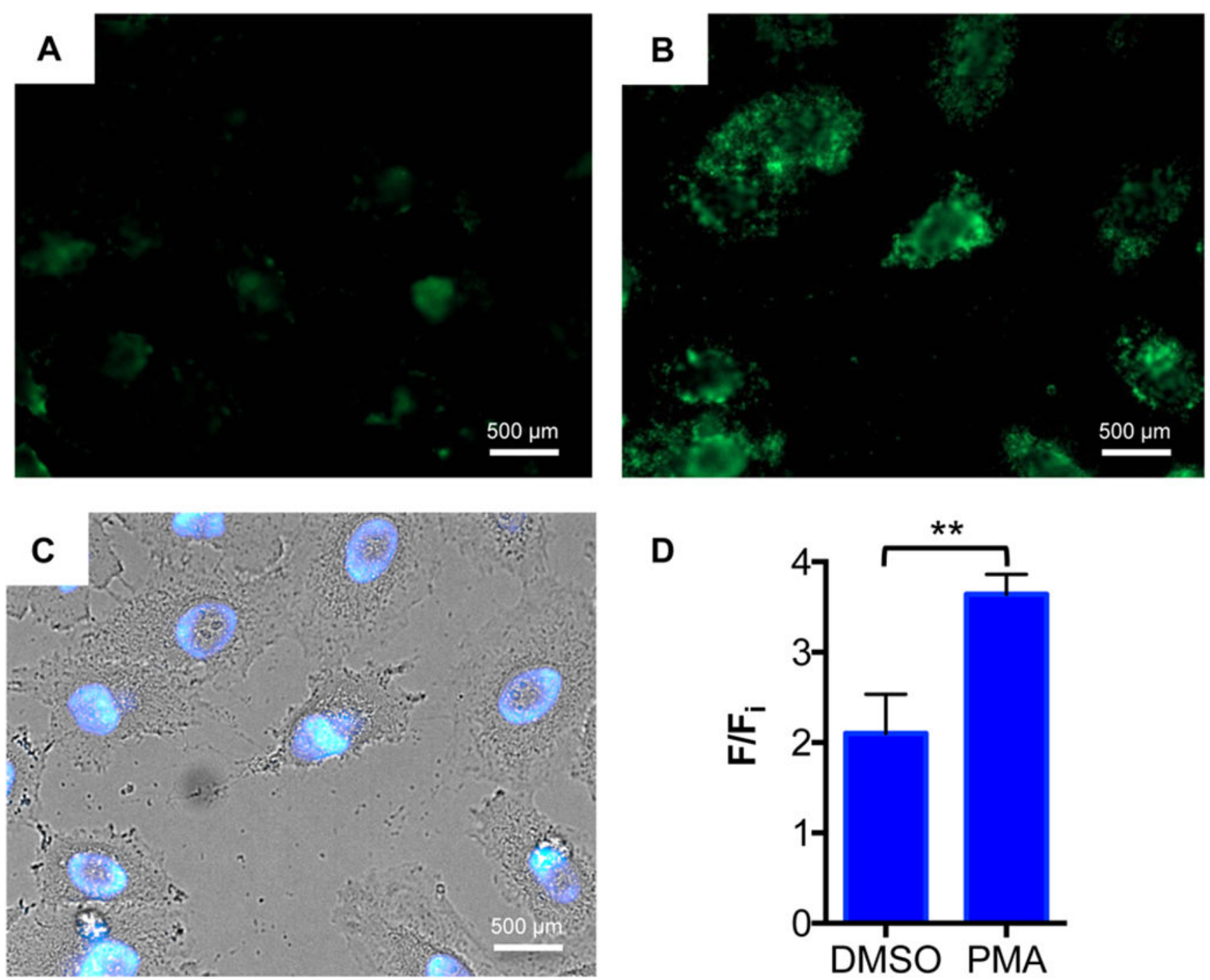

Figure 7.

Cellular fluorophore release in HeLa cells by endogenous, PMA-stimulated $\mathrm{H}_{2} \mathrm{O}_{2}$ generation. Cells were pretreated in DMEM containing (A) DMSO or (B) PMA (1 uM) and incubated at $37^{\circ} \mathrm{C}$ for $60 \mathrm{~min}$. Media was replaced with fresh DPBS containing $33(10 \mathrm{uM})$ and cells were incubated for an additional $60 \mathrm{~min}$ at $37^{\circ} \mathrm{C}$ before fluorescence was imaged (Zeiss Axio Observer Z1, 20× objective, GFP filter (Set $38 \mathrm{HE}$; ex = $470 \mathrm{~nm}$; em = 525 $\mathrm{nm})$ ). (C) Bright-field image of cells in panel B stained with Hoechst $33258(1 \mu \mathrm{M})$ and imaged using a DAPI filter (Set 68; ex = $377 \mathrm{~nm}$; em = $464 \mathrm{~nm}$ ). (D) Mean fluorescence intensities were calculated from three individual HeLa cells and set relative to the mean fluorescence intensity prior to treatments $\left(F / F_{i}\right)$. Error bars denote standard deviations; **, $P$ $<0.01$. 


\section{Prior studies}<smiles>[R]C(N)NC(=O)OCc1ccc(B2OC(C)(C)C(C)(CC(C)CO)O2)cc1</smiles>

This work
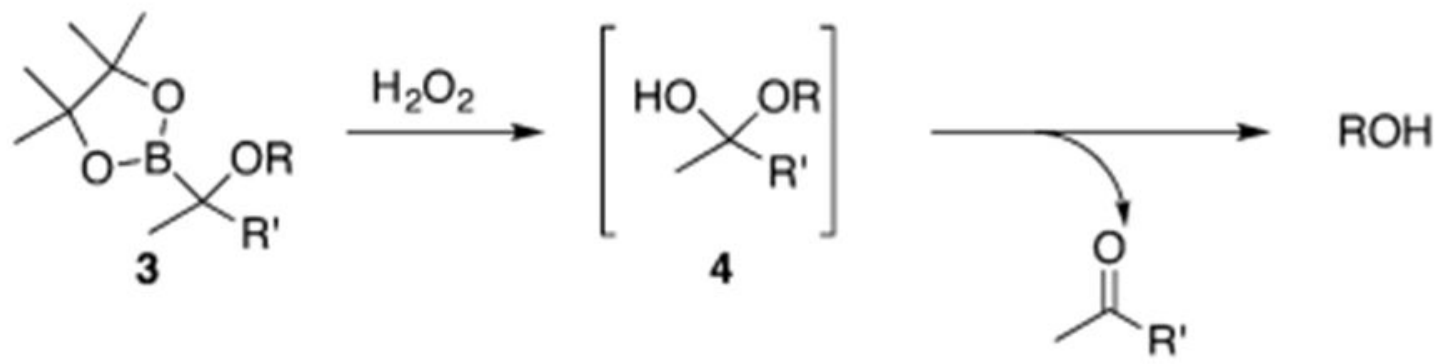

Scheme 1.

Alcohol Release through Boronate Oxidation 
<smiles>CCC(C)=O</smiles>

5<smiles>CC1(C)OB(B2OC(C)(C)C(C)(C)O2)OC1(C)C</smiles>

$\mathrm{ClCH}_{2} \mathrm{OMe}$ $\mathrm{Pr}_{2} \mathrm{NEt}, \mathrm{CH}_{2} \mathrm{Cl}_{2}$

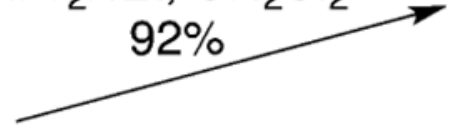

6

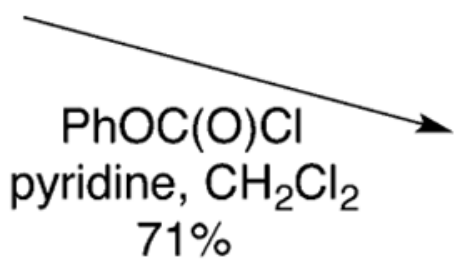

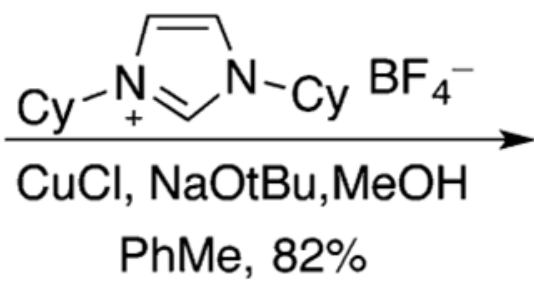

$\mathrm{PhMe}, 82 \%$

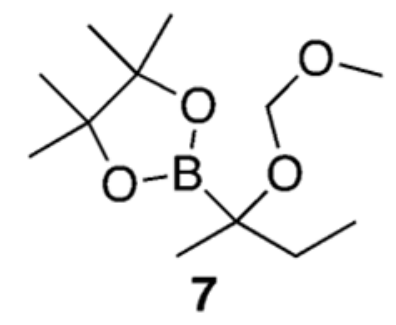<smiles>CCC(C)(O)B1OC(C)(C)C(C)(C)O1</smiles><smiles>CCC(C)(OC(=O)Oc1ccccc1)B1OC(C)(C)C(C)(C)O1</smiles>

8

Scheme 2.

$a$-Boryl Alcohol Synthesis and Functionalization 


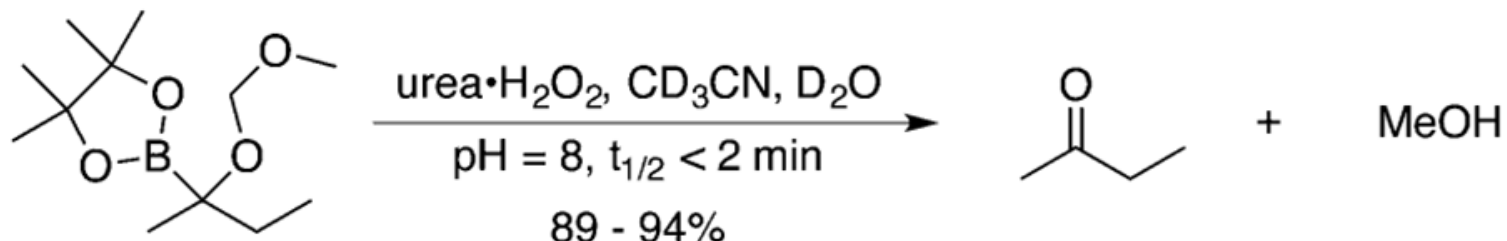

7

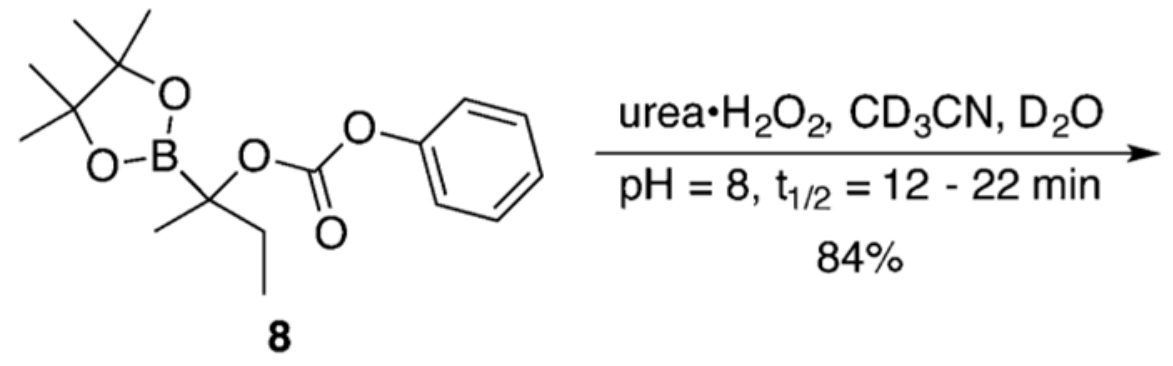<smiles>CCC(C)=O</smiles><smiles>Oc1ccccc1</smiles>

Scheme 3.

Oxidative Alcohol Release 
<smiles></smiles>

24<smiles>CCC(C)(OC#[SH])B1OC(C)(C)C(C)(C)O1</smiles>

25

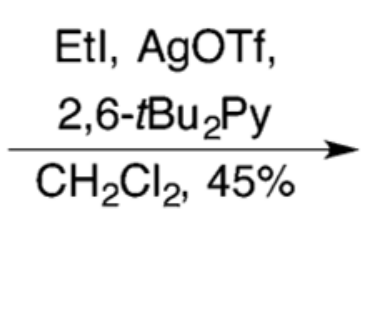

$X_{0-B}^{1}$<smiles></smiles>

15<smiles>CC[SiH2]CC(=O)N(C)C</smiles><smiles>CCC(C)(OCC(C)C)B1OC(C)(C)C(C)(C)O1</smiles>
17

Scheme 4.

Etherification in the Absence of Strong Base 
<smiles>COc1ccc(COCCC(C)=O)cc1</smiles>

26<smiles>COc1ccc([C@@H]2OCC[C@](C)(B3OC(C)(C)C(C)(C)O3)O2)cc1</smiles>

28
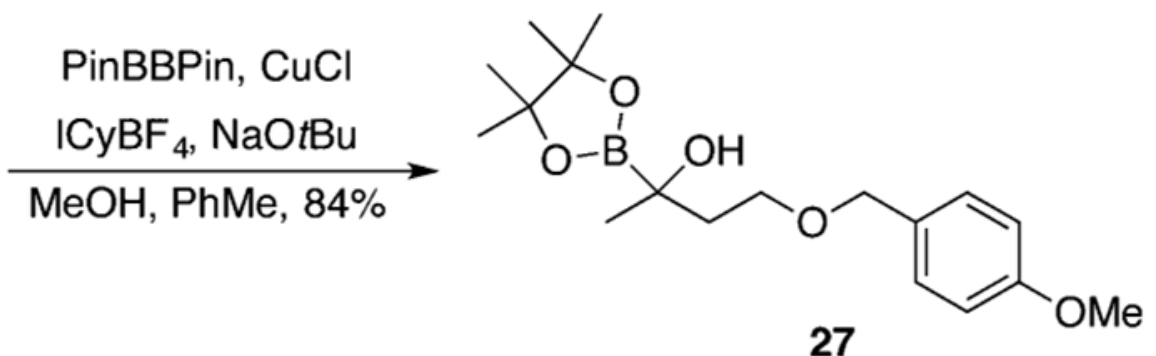

$\longleftarrow \frac{\mathrm{DDQ}, \mathrm{CH}_{2} \mathrm{Cl}_{2}}{0^{\circ} \mathrm{C}, 78 \%} \quad 27$ $0^{\circ} \mathrm{C}, 78 \%$

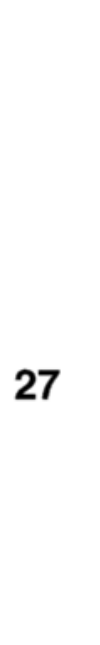

1. $\mathrm{H}_{2}, \mathrm{Pd} / \mathrm{C}, \mathrm{MeOH}$

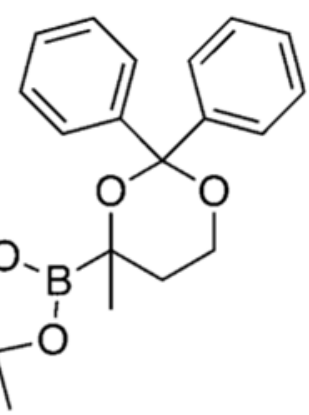

29

Scheme 5.

Synthesis of Cyclic Acetal Substrates 
<smiles>COc1ccc([C@H]2OCC[C@](C)(B3OC(C)(C)C(C)(C)O3)O2)cc1</smiles>

28<smiles>COc1ccc(C2OCCC(C)(O)O2)cc1</smiles>

30<smiles>COc1ccc(C=O)cc1</smiles><smiles>CC1(B2OC(C)(C)C(C)(C)O2)CCOC(c2ccccc2)(c2ccccc2)O1</smiles>

\section{$\mathrm{H}_{2} \mathrm{O}_{2} \cdot$ urea, $\mathrm{pH}=8.0$ $\underset{81 \%}{\stackrel{\mathrm{CD}_{3} \mathrm{CN}, \mathrm{D}_{2} \mathrm{O}, \mathrm{t}_{1 / 2}<2 \mathrm{~min}}{\longrightarrow}}$}<smiles>O=C(c1ccccc1)c1ccccc1</smiles><smiles>CC(=O)CCO</smiles>

\section{9}

Scheme 6.

Aldehyde and Ketone Release through Oxidative Acetal Cleavage 
<smiles>CCNc1ccc2cc([C@H]3OCC[C@@](C)(B4OC(C)(C)C(C)(C)O4)O3)c(=O)oc2c1</smiles><smiles>CCNCC</smiles><smiles>CCNc1ccc2cc([C@@H]3OCC[C@@H](C)O3)c(=O)oc2c1</smiles><smiles>Cc1cc(=O)oc2cc(OC(=O)OCc3ccc(B4OC(C)(C)C(C)(C)O4)cc3)ccc12</smiles>

34

Scheme 7.

Synthesis of a Latent Fluorophore 
Table 1.

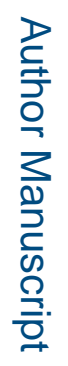

Alcohol Release Scope

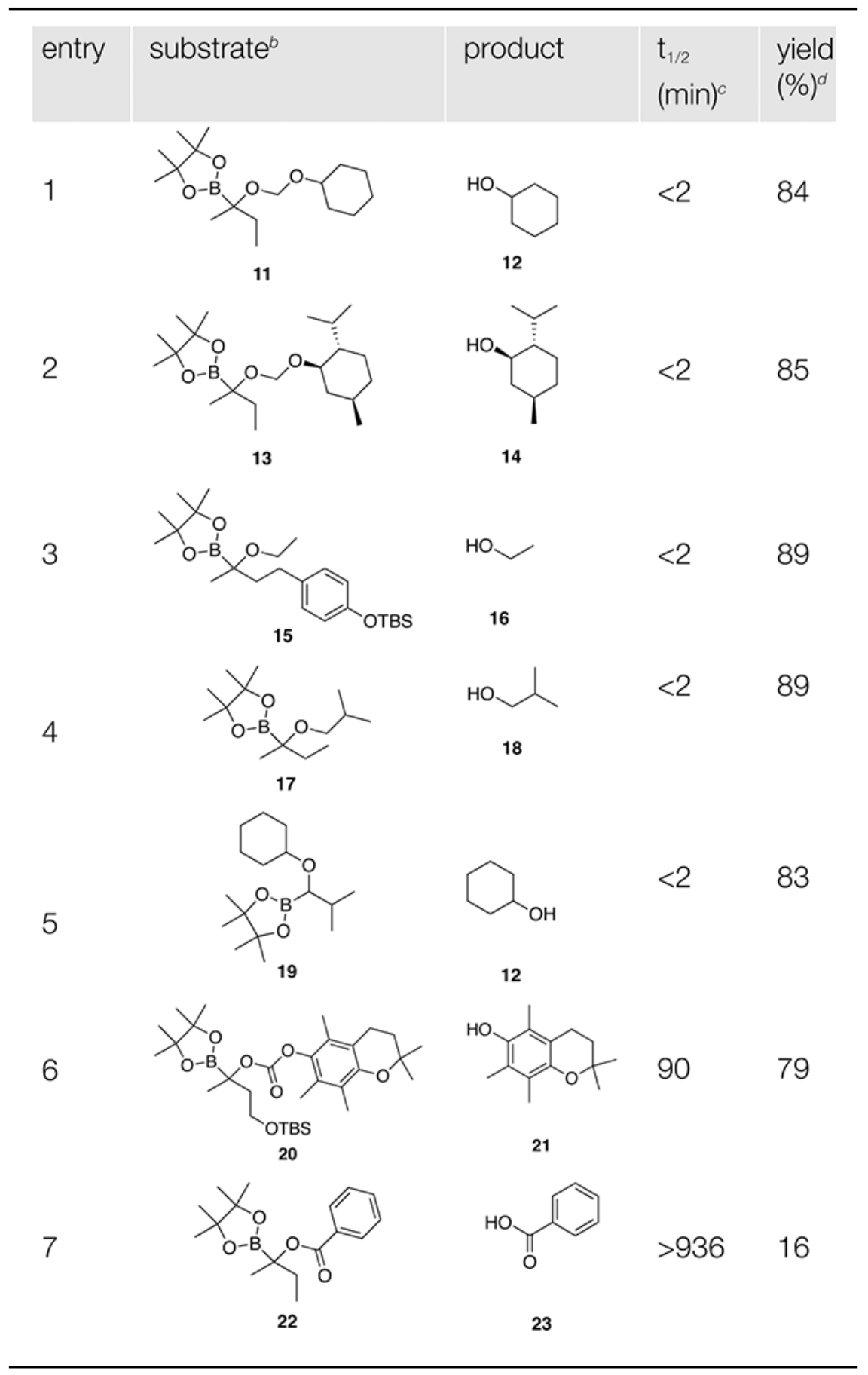

${ }^{a}$ Reactions run with 6-12 equiv of $\mathrm{H}_{2} \mathrm{O}_{2}$.urea at $\mathrm{pH} 8.0$ in $\mathrm{CD}_{3} \mathrm{CN}$ and $\mathrm{D}_{2} \mathrm{O}(5: 1)$ at $\mathrm{rt}$.

${ }^{b}$ See the Supporting Information for the preparation of the substrates.

J Am Chem Soc. Author manuscript; available in PMC 2020 March 16. 
${ }^{c}$ As determined by monitoring substrate consumption.

${ }^{d}$ Determined by ${ }^{1}$ H NMR through comparing to the internal standard 1,2-dimethoxyethane. 